\title{
Community Learning Center Efforts to Improve Information Literacy in the Community for Cyber Crime Prevention during a Pandemic
}

\author{
Sri Nurhayati $^{1 *}$, Safuri Musa ${ }^{2}$, Gumpanat Boriboon $^{3}$, Rina Nur'aeni ${ }^{1}$, Shindriani Putri ${ }^{1}$ \\ ${ }^{1}$ Institut Keguruan dan Ilmu Pendidikan Siliwangi, Indonesia \\ ${ }^{2}$ Universitas Singaperbangsa Karawang, Indonesia \\ ${ }^{3}$ Shrinakarinwirot University, Thailand \\ *Email: srinurhayati@ikipsiliwangi.ac.id
}

Submitted: 28 October 2020. Revised: 27 November 2020. Accepted: 12 February 2021

\begin{abstract}
This study explores the community learning centers' effort in improving the community's information literacy to prevent cybercrime during the pandemic era through an empirical examination of the phenomenon of pandemic COVID 19 social impacts in the specific context of Indonesia. The study used a simple research design approach with the case study method. The subject of this study consisted of five Community Learning Center's managers from Cimahi District (CLC Nurul Islam Al Husna), Garut District (CLC Ngejah), East Jakarta District (CLC Faradika), and Karawang District (CLC Ash Sholahiyah and CLC Sanggar Juang), and two community education experts from Indonesia. Data were analyzed using triangulation, including extensive interviews from five community learning center's managers, interviews with community education experts, as well as secondary data. The study found that community learning center's efforts consist of conducting virtual socialization and also mentoring the community on information literacy, revitalizing parenting education on guiding children during their screen time, activating community reading center to create a lively discussion, and fostering community's critical thinking and information assessment. The contribution of this study to the literature on community education consists of presenting empirical evidence on the real contribution of Community Learning Center in improving the community's information literacy level while preventing the wide spreading of cyber-crime during the pandemic COVID 19 era.
\end{abstract}

Key words: Community Learning Center, Information Literacy, Cyber Crime, Pandemic

How to Cite: Nurhayati, S., Musa, S., Boriboon, G., Nuraeni, R., \& Putri, S. (2021). Community Learning Center Efforts to Improve Information Literacy in the Community for Cyber Crime Prevention during a Pandemic. Journal of Nonformal Education, 7(1), 32-38.

DOI: http://dx.doi.org/10.15294/jne.v7i1.26883

\section{INTRODUCTION}

Corona Virus Disease or COVID was initially found in the Southern Chinese market in Wuhan, Hubei Province, China, in December 2019 is an illness that causes pneumonia or respiratory outbreaks (Cennimo, 2020; Huang et al., 2020). COVID-19 is now a pandemic in many countries around the world, including Indonesia. (World Health Organization, 2020).

In Indonesia, during the COVID season, the author observes that all activities, such as government offices, companies, and schools, are closed to avoid increasing coronavirus love during the time of closure. The library with a reading room/study room is also closed so that physical access to print collections and the circulation of the thesis and others are not available to view or borrow. To make good use of quality time, every student and worker must, whenever they are from home, provide an appropriate way of managing time at home. Then some agencies/groups/ academic organizations like community learning centers begin different online programs, including webinars, zooms, FDPs, workshops, competitions, and training sessions. Academics, researchers, teachers and librarians, and others, through their participation in a pandemic COVID-19 program, took action to make effective use of time. The community has undergone drastic changes in every aspect of its life, including economic, political, education, technology, religious information, mindset, and social behavior as a result of the COVID-19 pandemic (Aduloju, 2020; Elavarasan \& Pugazhendhi, 2020).

as the COVID-19 pandemic maintains public safety, it is required to restrict physical family presence to hospitalized patients. In response, the health system should quickly adapt the procedures and tools that are family-centered to avoid restrictions of physical presence. The strategy to maintain the integrity of the family should recognize the limited time and attention of doctors to devote themselves to learning new skills. Internet-based solutions can facilitate routine, predictable, and structured communications, which are family-centered care centers. However, reliance on technology can compromise patient privacy and exacerbate race, socio-economic, and geographic gaps for populations that do not have access to reliable Internet access, device, or technological literacy (Hart et al., 2020).

Indonesians consume a lot of news and information about C0V1D-I9 (Bilawar, 2020). Information 
on the spread of the COVID pandemic has spread rapidly through the media of information. A communication system that spreads so fast without any clear validity. This is all simply absorbed by the general public. Information is very important to the public; it is just that the general public needs the ability to understand real information. One of the social impacts of the COVID 19 pandemic is that today's interactions in the community are more common in cyberspace. The use of the internet and the uncontrolled dissemination of information can lead to various crimes in cyberspace or cybercrime (Widodo, 2013) ranging from the spread of hoax news, cyber-bullying to the crime of fraud on social media, and so on.

Cyber Crime is a deliberate act that violates criminal law (law and legal case), is done without defense or reasoning, and is punished by the state as a crime or offense. In studying the perpetrator there is no presumption that. People are criminals unless they are also considered guilty of reasonable doubt of a certain offense. (Brown et al., 2018)

Cybercrime is a term that refers to criminal activity with computers or computer networks into tools, targets, or places where crime is included in cyber crimes including online auction fraud, check counterfeiting, credit card fraud/carding, Confidencefraud, identity fraud, and child pornography. (Nodeland et al., 2019; Wahid \& Labib, 2005). Online crime is also called cybercrime since the attacker uses unique cyberspace information (Bossler \& Berenblum, 2019) Cybercrimes can be classified into different categories, including cybertrespass (e.g., unauthorized system access), cyberdeception/theft (e.g., identity theft, online fraud, digital piracy), cyber-porn/obscenity (e.g., child sexual exploitation materials), and cyber-violence (e.g., cyberstalking; cyber terrorism) (Hansen et al., 2019). Cybercrime is increasing very rapidly due to technological developments. This causes the handling of cybercrime to be a complex enough task that it must be done with the right framework (Poonia, 2014).

In this situation, The quality of information that comes to users from various media is unclear. People also begin to question the validity or authenticity, validity, and reality of the information it obtains. To make information again clear and effective, the public is required to have the ability to obtain and manage information (Iannuzzi, 2000; Mishra \& Mishra, 2010). Information literacy needs to be improved not only in the field of information of the current pandemic situation, but also there is an urgent situation of cybercrime improvement that is widespread throughout the archipelago, including the widespread of hoaxes, fraud, and other forms of cybercrime that need to be anticipated and prevented by the public.
The public must have an understanding of every public communication. The importance of literacy is understood by the community so that people can get information appropriately following their research. Information literacy is defined as the ability to recognize the need for information, how to access, evaluate, synthesize, and use information from multiple sources to achieve specific goals; understand economic, legal, and social issues relating to the ethical and social use of information, access and use of information (Association, 2008; Doyle, 1994; Lee \& So, 2014; Moeller et al., 2011; Weiner, 2012).

Raseroka (2006) trying to show that orality, as a communication system, shows its application to information literacy in the way people use words that are heard and spoken to exchange information to develop and maintain local wisdom and culture. This glorification of education towards public communication literacy enables the community to improve their ability to seek, find, analyze, evaluate, and communicate the information well, so that the community can increase their knowledge in communicating

His predecessor research has found that information literacy is a set of critical and skilled workplaces, reflecting the learning challenges inherent in the digital world economy, all of which depend on a highly skilled and innovative workforce. (Jackman \& Jones, 2002) Reading skills assessments must also consider the difficulty of the text, and measures of listening skills must praise the words spoken and their delivery. Where information literacy is considered necessary because as a synthesis of all literacy that can provide a solid systemic foundation for the mastery of information and communication technology, the impact is very beneficial for the economic growth of developing countries around the world. (Rudd, 2010)

Information literacy is where all the double reading and pushing activities to make readers captivated from the very beginning of life and give a lot of practice because the era of this information reading skills will allow users not only to survive but also to thrive. (de Jager \& Nassimbeni, 2007).

To try to explain the cause of evil, it is important to know who is committing the crime, who is the victim, and when and where the crime is done. This information can also be utilized by educational and legal practitioners to evaluate the effectiveness of crime-fighting techniques and to find things that require greater attention. One of the most widely debated premises underlying attempts to explain cybercrimes, among the criminologists and laymen, is the role of choice. The problem is the degree to which violators are encouraged or not driven by rational decision making. (Brown et al., 2018). Information circulating in the community is a very important part 
of efforts to enlighten and educate the public (Rahma et al., 2019). According to Bundy (2004), Information literacy is part of independent learning and lifelong learning. So that students can interpret learning not only as an obligation but as an experience of learning about everything and fulfilling curiosities.

Community learning centers have an essential role in providing education to society in realizing an information literate society that will ultimately prevent people from becoming victims of cybercrime. The Community Learning Center (CLC) is part of an institution that organizes informal and informal educational activities. CLC aims to socialize human resource development programs by providing lifelong learning for everyone. CLC focuses on literacy and sustainable education to support the education movement for all. CLC's programs include literacy education, equality education, early childhood education, youth coaching, religious coaching, and training courses. (Rahma et al., 2019). CLC as part of nonformal education has the main challenge of meeting the needs of the community in the lifelong learning process and also to develop themselves and community skills through the process of education or training (Shofwan et al., 2019).

This research will explore the Community Learning Center Efforts in Improving Communities Information Literacy to Prevent Cyber Crime during the Pandemic Era.

\section{METHODS}

This research was designed using a case study method with a simple research design approach. Case studies are a more appropriate approach used to answer research subjects related to "how or why," or when research is conducted with little chance of controlling the events to be studied, and the focus of the research is the current phenomenon in the community. (Yin, 2017).

Data collection techniques consisted of in-depth interviews from five Community Learning Center managers, interviews with community education experts, and secondary data. The subject of this study consisted of five Community Learning Center's managers from Cimahi District (CLC Nurul Islam Al Husna), Garut District (CLC Ngejah), East Jakarta District (CLC Faradika), and Karawang District (CLC Ash Sholahiyah and CLC Sanggar Juang), and community education experts. Data is collected through in-depth interviews and secondary data. The data collection phase is carried out concerning the role performed by CLC to improve the literacy of public information.

Data analysis is done by triangulating at each stage of data collection. The analysis process is con- ducted through the data collection stage, reducing data, presenting data, and drawing conclusions (Miles et al., 2014). Data collection is obtained from research subjects and related literature related to research. The reduction stage involves selecting existing data by selecting the collected data to be more focused on CLC's role in improving information literacy. The next stage of data presentation is done to give an overview of the data as a whole. The data of the findings in the field is presented in the form of narrative text to describe the role of CLC in improving information literacy. The last is the withdrawal stage of conclusion and verification. At this stage, it is done to look for the meaning of the data that has been collected. The verification process is carried out to test the veracity of any data obtained from all research subjects. The conclusion is presented in the form of a brief statement by analyzing the findings related to the research's focus, which is CLC's efforts in improving the community's literacy to prevent cybercrime.

\section{RESULTS AND DISCUSSION}

On a practical level, media literacy relates to the ability to access, analyze, evaluate, and communicate information in various formats, including printed and non-printed formats, analog formats, and digital formats. So the emphasis is on people's ability to use media that contain information and certain information sources which are increasingly infinite and complex. The importance of professional involvement in education can have a direct effect on increasing community literacy. Information literacy education emphasizes critical thinking, metacognitive and knowledge used to search for information in specific areas emphasized recognizing message quality, authenticity, and credibilityindonesians consume a lot of news and information about c0v1d-i9. (hobbs 2006).

the findings demonstrate the community learning center's real contribution to improving the quality of public information literacy. especially in this pandemic era, people need to be educated about the information that is widespread, easy, and fast. goyal (Goyal, 2012) says that cybercrime is very easy to spread and develop on social media because, through social media, every user can freely talk about anything without anyone watching. the five clc managers interviewed mentioned that activities to improve community literacy had been carried out, but there has not been a specific program to improve community literacy in preventing cybercrime.

based on interviews with clc managers, faradika mentioned that during this pandemic, clc faradika had held public speaking seminars for the general public 
conducted online. this activity aims to make the community has public speaking skills during the pandemic period. One of the functions of public speaking is to provide information, as Lucas (2009) explained that public speaking has the primary purpose of conveying information, persuading, and entertaining. By public speaking training can provide insights to the public on how to convey information to the public in a fair and proper, proportionate, honest, and credible way. indonesia itself is the thirdlargest country in the world that has serious concerns about the spread of hoax news (firmansyah 2017). educate the public to be careful in public speaking is compulsory to prevent the spread of hoaxes and cybercrime (e.g., spreading fraud to the public for a particular benefit).

Another effort made by CLC is to provide socialization and information literacy training for the community as the findings obtained from an interview with CLC Sanggar Juang that moves by carrying out information filtering training that is aired regularly for millennials every week. Utilizing the gadgets owned by the training starts by reading the information on social media, then checking the accuracy of the information at various sources, ranging from utilizing existing online sites and media, and then concluding. Through this socialization, people increasingly understand what to do when obtaining information. As stated by Hardika, Aisyah, and Kurniawan (Hardika et al., 2020) that information and news about Covid-19 is something valuable and meaningful that must be managed as learning materials to become new knowledge for the community because it is something that has never been heard by some people.

Furthermore, based on interviews with CLC manager Nurul Islam Al Husna during the current pandemic situation, online shopping becomes a reasonably popular community activity. People's concerns about getting out of the house caused them to choose to make ends meet by doing online shopping. Therefore, CLC Nurul Islam Al Husna held a digital literacy workshop to improve economic empowerment. The workshop also improves the literacy of public information about digital platforms that people can use to transact the economy online and also explains how to transact properly online, avoiding fraud and actions that lead to other cybercrime related to economic transactions in the market. Information literacy is deemed necessary because it is a synthesis of all literacy that can provide a solid systemic foundation for mastery of information and communication technology, its impact is very beneficial for the economic growth of developing countries around the world (Rudd, 2010).
Further findings show efforts to improve literacy by CLC through mentoring for the community. Based on the interview results with CLC Ngejah, the literacy program is implemented by guiding students, youth, and the general public about the proper use and utilization of media. Coaching is conducted in discussions about the positive and negative impacts of television, blog training, and a healthy internet. Through the media literacy movement, people are expected to have the ability to access media, analyze media content in context, and be able to produce information in various forms and types of media. According to Sujianto, Zaini, and Rohmah (2019) mentoring activities are very effective in improving one's knowledge and literacy skills.

The establishment of various literacy communities can also be a solution as an effort to improve community literacy. Basuki et al. (2013) stated that with a community, one would not feel alone because there is room to share stories, experiences, sorrows, and other interests. The interview results with CLC As-Sholahiyah revealed that the efforts were made by forming a community engaged in information literacy named Assolahiyah Community Information Group (KIM). This activity with the information office. This community conducts many activities related to literacy education, such as the establishment of Community Reading Park (TBM), counseling and socialization related to the maximum use of technology for activities to support online learning progress. The community can be a forum for people to gain knowledge and skills in information literacy, mainly to prevent cybercrime. The results of Juditha's research (2019) showed that in preventing hoaxes, the role of the community succeeded in improving the literacy of members' information by itself, so that seven pillars of information literacy were built, ranging from information identification, coverage, planning, information collection, evaluation, researching and presentation of information.

Furthermore, interviews with education experts mentioned that efforts to improve literacy information in the community are quite complicated because, for things like this, CLC managers are not sensitive enough in contributing to actual issues that occur in the community, such as information literacy. CLC programs implemented tend to still focus on conventional programs. This is not following the concept of lifelong education, which is the principle of CLC, as stated by Fischer (2000) that lifelong learning applied in clc is carried out to expand learning opportunities so that one can learn many things following certain situations, following the needs of the community. several steps can be taken to improve public information literacy, such as activating the community reading park, conducting literacy 
movements, creating programs that suit the community's interests and needs, courses, and strengthening family education program.

Based on the above findings, socialization, research, and mentoring for the community conducted by CLCs aim to improve the information community's knowledge and literacy skills, where the public will be able to find, select and retrieve the information needed and can spread the information wisely. As Catts and Lau (Catts, 2012) reveal that a literate person is a person who can: (1) recognize their information needs, (2) find and evaluate the quality of the information obtained, (3) store and retrieve information, (4) utilize that information effectively and ethically, and (5) be able to disturb that information to create and transfer knowledge. these five elements are essential to creating information-literate people to prevent cybercrime.

Various ways that can be done to increase public information literacy in preventing cybercrime, such as virtual socialization and also assistance to the community about information literacy, revitalizing parenting education in guiding children during screen time, activating community reading centers to create discussions. Which lives and fosters community critical thinking and informed judgment. The role of CLC as a source of learning for the community is indeed needed in the current situation. The community will gain additional knowledge through various activities anytime and anywhere. In nonformal education, all activities that occur in the community are part of the learning process (Gibson et al., 2018). The learning process carried out by CLC is carried out collaboratively by the community to carry out learning activities informally (Swaminathan, 2007). According to Bundy (2004) literacy information cannot be a product of one course. Lau (2006) states that institutional collaboration in every education stakeholder is very important

\section{CONCLUSION}

Community Learning Center as part of an educational organization has tried varied ways in offering programs to improve the level of information literacy for the community to prevent the widespread of cybercrime in the community during the pandemic time. Several efforts that can be made by the community learning center in increasing the level of information literacy of the community while preventing the widespread cyber-crime in the COVID-19 pandemic era is to socialize virtually and also mentor the public about information literacy, revitalize parenting education in guiding children during screen time, activate community reading center to create a lively discussion and foster critical thinking and public information. Further research needs to be done to measure the most effective effort in improving the community's information literacy and also which effort is the best way to prevent cybercrime.

\section{REFERENCES}

Aduloju, E. T. (2020). Media and Information Literacy: A Critical Response to the Challenge of 'Infodemic'in the Covid-19 Pandemic Era in Nigeria. Resisting Disinfodemic Media and Information Literacy, 80.

Association, A. L. (2008). Presidential committee on information literacy. Http://Www. Ala. Org/Ala/Acrl/Acrlpubs/Whitepapers/Presidential. Cfm.

Basuki, Y., Akbar, R., Pradono, P., \& Miharja, M. (2013). Komunitas online: Pergeseran terminologi komunitas dari Geddesian menuju era informasi dalam konteks perencanaan transportasi perkotaan. TATALOKA, 15(1), 63-75.

Bilawar, P. B. (2020). Lockdown Period and Information Sources. International Journal of Engineering Research And Management (IJERM), 7(06), 7-16.

Bossler, A. M., \& Berenblum, T. (2019). Introduction: new directions in cybercrime research. Journal of Crime and Justice, 42(5), 495-499.

Brown, S. E., Esbensen, F.-A., \& Geis, G. (2018). Criminology. In Criminology: Explaining Crime and its Context, Tenth Edition. Routledge.

Bundy, A. (2004). Australian and New Zealand information literacy framework. Principles, Standards and Practice, 2. https://adbu.fr/wpcontent/uploads/2013/02/Infolit-2nd-edition.pdf

Catts, R. (2012). Indicators of adult information literacy. Journal of Information Literacy, 6(2), 4-18.

Cennimo, D. J. (2020). Coronavirus disease 2019 (COVID-19) treatment \& management: approach considerations, medical care, prevention. Medscape Online.

de Jager, K., \& Nassimbeni, M. (2007). Information Literacy in Practice: Engaging public library workers in rural South Africa. IFLA Journal, 33(4), 313-322.

Doyle, C. S. (1994). Information literacy in an information society: a concept for the information age. In Literacy.

Elavarasan, R. M., \& Pugazhendhi, R. (2020). Restructured society and environment: A review on potential technological strategies to control the COVID-19 pandemic. Science of The Total Environment, 138858. 
Firmansyah, R. (2017). Web klarifikasi berita untuk meminimalisir penyebaran berita hoax. Jurnal Informatika, 4(2).

Fischer, G. (2000). Lifelong learning-more than training. Journal of Interactive Learning Research, 11(3), 265-294.

Gibson, D., Broadley, T., Downie, J., \& Wallet, P. (2018). Evolving learning paradigms: Re-setting baselines and collection methods of information and communication technology in education statistics. Journal of Educational Technology \& Society, 21(2), 62-73.

Goyal, S. (2012). Facebook, twitter, google+: Social networking. International Journal of Social Networking and Virtual Communities, 1(1), 16-18.

Hansen, R. A., Seigfried-Spellar, K., Lee, S., Chowdhury, S., Abraham, N., Springer, J., Yang, B., \& Rogers, M. (2019). File Toolkit for Selective Analysis Reconstruction (FileTSAR) for LargeScale Networks. Proceedings - 2018 IEEE International Conference on Big Data, Big Data 2018.

Hardika, H., Aisyah, E. N., \& Kurniawan, T. (2020). Literacy about Covid-19: Trending Words, News Sources, Comprehension, and Community Curiosity in Perspectives Nonformal Education. Journal of Nonformal Education, 6(2), 161-167.

Hart, J. L., Turnbull, A. E., Oppenheim, I. M., \& Courtright, K. R. (2020). Family-Centered Care During the COVID-19 Era. Journal of Pain and Symptom Management, 60(2), e93-e97.

Hobbs, R. (2006). Multiple visions of multimedia literacy: Emerging areas of synthesis. International Handbook of Literacy and Technology Vol. II, 15.

Huang, C., Wang, Y., Li, X., Ren, L., Zhao, J., Hu, Y., Zhang, L., Fan, G., Xu, J., Gu, X., Cheng, Z., Yu, T., Xia, J., Wei, Y., Wu, W., Xie, X., Yin, W., Li, H., Liu, M., ... Cao, B. (2020). Clinical features of patients infected with 2019 novel coronavirus in Wuhan, China. The Lancet, 395(10223), 497-506.

Iannuzzi, P. (2000). Information literacy competency standards for higher education. Community and Junior College Libraries, 9(4), 63-67.

Jackman, L. W., \& Jones, L. D. (2002). Information Literacy, Information Communications Technologies (ICT) and the Nongovermental Organization (NGO)/non profit world: as practitioner's perspective. Information Literacy Meeting of Experts, $1(1), 1-21$.

Juditha, C. (2019). Literasi Informasi Melawan Hoaks Bidang Kesehatan di Komunitas Online. Jurnal ILMU KOMUNIKASI, 16(1), 77.

Lau, J. (2006). Guidelines on information literacy for lifelong learning. IFLA, Veracruz. https://cf2- www.ifla.org/files/assets/informationliteracy/publications/ifla-guidelines-en.pdf

Lee, A. Y. L., \& So, C. Y. K. (2014). Media literacy and information literacy: Similarities and differences. Comunicar. https://doi.org/10.3916/C422014-13

Lucas, S. E. (2009). The Art of Public Speaking 11th Edition. Boston. Mc. Graw Hill.

Miles, M. B., Huberman, A. M., \& Saldaña, J. (2014). Qualitative data analysis: A methods sourcebook. 3rd. Thousand Oaks, CA: Sage.

Mishra, R. N., \& Mishra, C. (2010). Relevance of information literacy in digital environment. Journal of Emerging Trends in Computing and Information Sciences, 1(1), 48-54.

Moeller, S., Joseph, A., Lau, J., \& Carbo, T. (2011). Towards media and information literacy indicators. Background Document of the UNESCO Expert Meeting (Bangkok, Thailand, 4-6 November 2010).

Nodeland, B., Belshaw, S., \& Saber, M. (2019). Teaching Cybersecurity to Criminal Justice Majors. Journal of Criminal Justice Education, 30(1), 71-90. https://doi.org/10.1080/10511253.2018.1439513

Poonia, A. S. (2014). Cyber Crime: Challenges and its classification. International Journal of Emerging Trends \& Technology in Computer Science (IJETTCS), 3(6), 119-121.

Rahma, R. A., Zulkarnain, Z., Desyanty, E. S., \& Wahyuni, S. (2019). The Role of Community Learning Center (CLC) in Providing Nonformal Education Services Based on Entrepreneurship. Journal of Nonformal Education, 5(2), 109-116.

Raseroka, K. (2006). Information Literacy Development within Oral Cultures: Challenges and Opportunities within a Southern African Country. IFLA Conference Proceedings, 9(5), 1-14.

Rudd, R. E. (2010). Improving Americans' health literacy. New England Journal of Medicine, 363(24), 2283-2285.

Shofwan, I., Yusuf, A., Suryana, S., \& Widhanarto, G. P. (2019). Evaluasi Program "Model Logical Framework" untuk Pengelola Pusat Kegiatan Belajar Masyarakat (PKBM). JURNAL PANJAR: Pengabdian Bidang Pembelajaran, 1(1), 59-64.

Sujianto, A. E., Zaini, Z., \& Rohmah, L. (2019). Pendampingan Literasi Keuangan Syariah Penerbit Cahaya Abadi Tulungagung. E-Dimas: Jurnal Pengabdian Kepada Masyarakat, 10(1), 116. Swaminathan, R. (2007). Educating for the "Real World": The Hidden Curriculum of Community Service-Learning. Equity \& Excellence in Education, 40(2), 134-143.

Wahid, A., \& Labib, M. (2005). Kejahatan Mayantara (cyber crime). Refika Aditama. 
Sri Nurhayati et al. / Journal of Nonformal Education 7 (1) (2021): 32-38

Weiner, S. A. (2012). Institutionalizing Information Literacy. Journal of Academic Librarianship.

Widodo. (2013). Memerangi cybercrime: karakteristik, motivasi, dan strategi penanganannya dalam perspektif kriminologi. Aswaja Pressindo.
World Health Organization. (2020). Q\&A on coronaviruses (COVID-19). In Who.

Yin, R. K. (2017). Case study research and applications: Design and methods. Sage publications. 